\title{
History Teaching to Promote Positive Community Relations in Northern Ireland: Tensions Between Pedagogy, Social Psychological Theory and Professional Practice in Two Recent Projects
}

\author{
Alan McCully and Jacqueline Reilly
}

\section{INTRODUCTION}

Prior to the Belfast (Good Friday) Agreement (1998), Northern Ireland (NI) experienced 30 years of violent political conflict, which was widely but simplistically portrayed as a religious conflict; while the protagonist communities were broadly labelled Catholic and Protestant, these religious labels signify political, cultural and national identity preferences and objectives. The label Catholic is associated with mainly Nationalist or Republican and Irish identities, with a reunification of the island of Ireland as an objective. The label Protestant is associated with mainly Unionist or Loyalist and British identities, with NI remaining part of the United Kingdom (UK) as an objective. The Good Friday Agreement

\footnotetext{
A. McCully $(\square) \cdot$ J. Reilly

Ulster University, Coleraine, Northern Ireland e-mail: aw.mccully@ulster.ac.uk

(C) The Author(s) 2017

C. Psaltis et al. (eds.), History Education and Conflict Transformation, DOI 10.1007/978-3-319-54681-0_12
} 301 
1998, recognising both groups and establishing a consociational devolved government, led to a greatly reduced level of violence, but the two communities remain polarised in many ways. This polarisation persists in a segregated education system with a large majority of pupils attending schools, which are classed as Controlled (mainly Protestant pupils) or Maintained (mainly Catholic pupils) with a small and very slowly growing integrated sector attended by approximately $7 \%$ of pupils (Furey et al. 2016, p. 3). A major focus of government continues to aspire to improvement in community relations, with a range of policy documents produced since 1998 leading to the Shared Future, Together Building a United Community strategy (Northern Ireland Government 2013 ) backed up by a raft of legislation. The latter seeks to ensure equality and requires that service providers and public sector organisations fulfil a duty to promote good relations.

Since the outbreak of violence in NI in 1968, educators have responded in three ways to bring about a more peaceful society: by seeking to break down this segregated education system and creating common schools; by accepting segregation as a reality and fostering meaningful contact between institutions to break down barriers; and by pursuing societal change through curriculum innovation irrespective of whatever school structures are in place. These approaches have evolved and overlapped, as the political situation has moved towards post-conflict, but essentially all three strategies currently continue to be visible (Gallagher 2004, pp. 119-135; 2016).

The curriculum in NI remains one that is predominantly organised through established subject disciplines, but since the introduction of statutory provision in the 1990s (revised in 2007) it contains overarching objectives which aspire to bettering community relations, thus implicitly contributing to group reconciliation (Smith 2005; CCEA 2007). These objectives impact on all subject teachers, but have particular implications for teachers of history, which is included in the NI Curriculum at primary level in Key Stages 1 and 2 (ages 5-11 years) as part of the learning area 'The World Around Us' and also at secondary level in Key Stages 3 and 4 (ages 11-16 years) as a discrete subject; all pupils study history to the end of Key Stage 3 (age 14). While their established role continues to be defined by the disciplinary rigour of their subject, history teachers are also expected to acknowledge their potential as educators to 
facilitate greater societal understanding and attitudinal change in young people (Richardson and Gallagher 2011; McCully 2012). Consequently, curricular and pedagogical innovations have been advocated to advance the subject's social utility, often supported by external funding for specific projects. Two such recent projects, Facing Our History, Shaping the Future (FOHSTF) and Teaching Divided Histories (TDH), are featured in this work. FOHSTF, funded variously by the International Fund for Ireland, the NI Office of the First and Deputy First Minister and the Irish Department of Foreign Affairs since 2013, provides free training for teachers and student teachers as well as workshops and residential courses for pupils. In its first phase, up to 2013, 280 teachers and student teachers attended FOHSTF training sessions and 1400 students in secondary schools experienced project workshops and residential courses (ETI 2013, p. 2). TDH is funded by the European Regional Development Fund under PEACE III. It also provides free training for teachers (internationally as well as in NI), and digital resources, lesson plans, teaching and evaluation materials are available to download from the website. In all, 84 teachers from 24 schools on both sides of the Irish border attended TDH training between 2011 and 2014 to prepare them to work with students in the 14- to 15-year-old age group (Gannon 2014, p. 7).

Education addressing community relations in Northern Ireland has been extensively researched, yet interestingly, individual academic disciplines at tertiary level have tended to concentrate on different areas. Educationalists have focused on curriculum issues, associated resources and pedagogy, while social psychologists have mainly explored the dynamics, effects and implications of cross-cultural contact on young peoples' attitudes and behaviour. Thus, potentially fertile areas for interdisciplinary collaboration between history educators and social psychologists may have been neglected. This chapter examines the aspirations of the NI Curriculum (with a focus on history) to contribute to greater community understanding and the expectation, as illustrated by FOHSTF and TDH, that history teaching, and teachers, should accept a major responsibility for this. The stances of the two projects are examined to ascertain the implications for approaches teachers might take and the potential benefits of a more explicit relationship between history teaching and social psychology concepts and theories are explored. 


\section{History Teaching and Community Relations}

Attention has been frequently drawn to the negative use of history in conflict situations. The promotion by a dominant group of a partisan historical narrative has often been used to support an ideological position which bolsters that group's political control at the expense of those deemed 'suspect' or 'inferior' (Bush and Saltarelli 2000; Smith and Vaux 2003; Davies 2004; Cole 2007). History teaching has thus often been associated with shaping the development of particular forms of national identity, particularly in newly independent states (e.g. Korostelina 2010). Consequently, history teaching is highlighted as an aspect of educational policy, which needs to respond positively if sustainable peace is to be achieved (Smith and Vaux 2003; Cole 2007). Therefore, educational reformers in contested contexts have acknowledged that reaching consensus on an agreed common narrative is highly problematic and instead have argued for history teaching which adheres to the subject's disciplinary process, thus giving students access to the provisional and contested nature of historical knowledge (McCully 2012). Drawing on the work of the Schools' Council History Project (Shemilt 1980) established in the 1970s, it is argued that a history curriculum that opens the past up to the consideration of different interpretations, provided that these are underpinned by valid historical evidence, can provide a greater understanding of the nature of conflict and challenge prevailing ideological certainties, which are often biased in divided societies. It can open up possibilities for greater mutual understanding by acquiring insight into the thinking of the 'other' and develop critical faculties, which, in turn, might help move society beyond conflict, thus contributing to reconciliation. However, the advocacy for enquiry-based multi-perspective history has tended to run ahead of research studies that confirm its efficacy in bringing personal and group transformation. This may result from a conviction by progressive educators that a constructivist approach, where students actively engage in historical enquiry, analysing, evaluating and interpreting sources in order to develop historical interpretations, offers a clear pathway in situations where emotive positions are deeply held, whether in favour of or against biased conclusions. However, there is a small body of empirical research with young people that does (tentatively) indicate positive outcomes from an enquiry approach (Barton and McCully 2005, 2010, 2012; Goldberg 2013; Kolikant and Pollack 2015). 
As early as the 1970s, innovative teachers in NI saw the potential to use evidential enquiry and perspective-taking to prise open students' restricted understandings of the past by challenging partial accounts acquired in families and communities. When the first statutory common curriculum was introduced in 1991 (three years before the first ceasefires brought an initial pause to endemic violence and seven years before the Good Friday Peace Accord), it was notable that the proposals offered by the working party set up to advise on history were largely accepted by teachers from both unionist and nationalist backgrounds. This was despite deep societal divisions and an education system, which reflected these divisions. The history curriculum at secondary level (compulsory for ages 11-14) harnessed the disciplinary framework to the study of key events from Ireland's past. Students were asked to study periods of history deemed essential for understanding the history of Ireland, but importantly, these were placed within wider British and European contexts (DENI 1991). The document argued for 'breadth, balance and coherence; that multiple interpretations of events be presented in a balanced way, with equal attention to the experiences and perspectives of both communities'. Teaching from a disciplinary base presents pedagogical challenges, and teachers have varying degrees of understanding of what is required in implementing this in practice. Apart from the challenges of dealing with contentious issues and having to take into account the potential influence of their own community allegiances, they also have to get beyond the mere transmission of historical knowledge to encourage critical thinking among their students (Smith 2005, pp. 148-150; Kitson 2007). Despite this, there is evidence-from academic research and government inspection reports-that, in the main, teachers value the aims of the curriculum and, despite shortcomings, have tried to approach Irish history in a fair and even-handed way (Education and Training Inspectorate 2006; McCombe 2006).

As already indicated, research into the impact of historical learning resulting from the 1991 history curriculum in Northern Ireland suggests that it has had some positive outcomes (Barton and McCully $2005,2010,2012$ ). These papers were based on data collection involving interviews with 253 students, in groups of 2 or 3 , from 11 different schools representative of a variety of demographic, social and educational contexts. Findings indicated that the enquiry approach was welcomed by young people. It had fostered criticality and had some success in helping 
them make sense of the range of interpretations of the past they encounter inside and outside school. However, significant limitations were also identified. Despite recognising the more balanced and discursive nature of school history when studying Ireland's past, most students' thinking was nevertheless clearly influenced by their respective community perspectives. This raises questions as to the emphasis of current practice on historical understanding as the basis for challenging partisan history. This, and other work (McCully 2005; Bell et al. 2010), suggests that young people often have strong emotional ties to particular cultural and political positions, which may hinder critical thinking processes, particularly when encountering sensitive historical material. Hence, teachers may need to take greater heed of the affective dimension of cognition, which is so strongly associated with national and cultural identity, and adapt their teaching approaches accordingly. However, little attention, to date, has been paid to the potential contribution of theories of social cognition, which may have something to offer in terms of understanding and addressing these issues.

Research outputs have influenced subsequent curriculum developments. When the curriculum was revised in 2007, nine years after the Belfast (Good Friday) peace accord, the enquiry dimension within history was consolidated further and the focus on the subject's social utility in a post-conflict context was strengthened. For example, it is a statutory requirement of the current provision that teachers explore with students the impact of history on their sense of identity, culture and lifestyle, its role in influencing stereotypes and the way the past can be used and abused in contemporary politics (CCEA 2007). More explicitly than before, these changes recognise that young people's understanding of the past influences their experiences and views in the present, which seems to suggest that there is a potential for social psychological theories and concepts to be incorporated into the curriculum. Before probing the two curriculum initiatives, FOHSTF and $\mathrm{TDH}$, in terms of content relating to social psychological concepts, first it is necessary to examine the potential relationship between social psychology, social cognition and history teaching in divided societies at a theoretical level. 


\section{Social Psychology, Social Cognition and History TEACHING}

A range of potentially relevant and established social psychological theories can be identified as relevant to history teaching in a divided society, including social categorisation and Social Identity Theory (Tajfel and Turner 1986), stereotype threat (e.g. Steele 1997) and attribution theory (Heider 1958).

Categorisation has been dubbed 'the cognitive foundation of all forms of prejudice' (Brown 2010, p. viii). Using an information processing analogy, one of the prime strategies used for the purpose of avoiding information overload is categorisation, which allows us to understand the environment rather more easily than if we had to evaluate each stimulus individually to identify it. Categorisation in terms of social cognition, then, is nothing more than the brain taking useful short cuts to understanding. Yet this universal cognitive process has huge implications for those teaching in subject areas such as history, because of its close associations with prejudice via stereotyping and with Social Identity Theory (Tajfel and Turner 1979), which has been widely applied to research in NI.

Social Identity Theory research over the last three decades has produced evidence of potential interest to teachers of history and other disciplines where identity issues may be significant. It is now well established that individuals simultaneously hold multiple social identities, may develop new identities and can embrace superordinate identities. In NI, the possible utility of a Northern Irish superordinate identity for reducing sectarian attitudes has long been discussed (Trew 1998). Recent census data (NISRA 2011) indicate that this identification is on the increase although it must be remembered that those espousing a Northern Irish identity might still simultaneously maintain a strong affiliation to traditional British or Irish national identities.

As a result of research in contested spaces, it is argued that a 'hot' rather than a banal form of national identity (Billig 1995) is actively constructed (Stevenson and Muldoon 2010) although as Skey (2009) points out these are neither fixed nor discrete, and Jones and Merriman (2009) have suggested 'everyday nationalism' as an alternative, more dynamic term combining banal and hot elements. In such circumstances, it is clear that the same contextual information (such as historical events) may be construed by different groups (including political actors) to support 
more than one claim to national identity. It is also clear that humans categorise as much as possible, so they also categorise themselves and other people into groups (social categorisation), they identify with some groups but not others (social identification) and they compare groups that they belong to with those that they do not (social comparison), often in a way that bolsters their own identity.

Thus, social identity and categorisation are closely related to the development of stereotypes and that negative stereotypes of out-groups are a fairly inevitable result. Moreover, such stereotyping tends to be automatic in character; that is, the individual has minimal if any awareness and/or control over it. Stereotyping is also pervasive and notoriously resistant to change (e.g. Geeraert and Yzerbyt 2007). There has been a wealth of research on identity, stereotypes, prejudice, and these theories have not only been tested but also used to develop interventions aimed at reducing prejudice. The contact hypothesis (Allport 1954), based on the idea that getting to know members of out-groups would challenge negative stereotyping and, hence, 're-individuate' members of the out-group, has led to decades of research culminating in evidence that one important reason for the positive effect of contact is reduction in the anxiety commonly experienced when in the presence of the outgroup (Hewstone 2003).

It would seem then that there is a great deal of theory and evidence about social cognition, which paints a mixed picture of the prospects for changing prejudiced attitudes. If identity formation, and thinking about in-groups and out-groups, is so pervasive, automatic, resistant to change, speedy and unconscious, one might be tempted to conclude that there is little teachers can do to reduce prejudice in contested social contexts. And yet we have noted above evidence from history classes in NI that some pupils can and do develop sound historical understandings in parallel with their own strong community identities and that attitudes may change as a result (Barton and McCully 2005, 2010, 2012). If one of the implicit aims of history education in NI is prejudice reduction, then some of the more recent developments in the understanding of social cognition might inform practical measures to intervene in these processes. 
Two of these areas are 'stereotype threat' and Situational Attribution Training. The former has been shown to influence performance when an individual believes that they will perform poorly at a task because of their make-up or background. However, Johns et al. (2005) found that by teaching about stereotype threat, 'Knowing is half the battle' or in other words this effect could be counteracted. This might be of interest to history teachers where some pupils might feel disadvantaged when studying history that is perceived to be that belonging to 'the other'. Acknowledging this at the outset might help to ensure that those pupils who would benefit from learning about less familiar historical perspectives do so, rather than simply accept that these perspectives are too difficult for them to understand and accept.

Situational Attribution Training (e.g. Stewart et al. 2010) in educational settings had been developed on the basis of attribution theory. This addresses how we decide whether an individual's actions are due to context or to their own characteristics (disposition) and relates to stereotyping, as negative acts are more often attributed to situation for ingroup members and to disposition for out-group members. Experiments have shown that automatic stereotyping can be reduced by repeatedly choosing situational explanations over dispositional ones for behaviours. This work took place in controlled conditions over a lengthy period, but in principle, situational explanations of actions resonate with contemporary arguments relating to empathetic understanding in history. Rather than asking young people to 'imagine you are' someone in the past, they should be encouraged to try to understand why individuals acted the way they did in the circumstances pertaining at the time (Lee and Shemilt 2011).

The principal point of this section is to argue that as theories and evidence in relation to the social cognition processes involved in prejudice become better understood, so too does understanding of how best to intervene in these processes. We now turn to examine two recent innovations in history teaching in NI designed to contribute to better intergroup relations. The aim is to analyse to what extent they may have been informed by social psychological theories and concepts, and how they might be better informed in this regard. 


\section{Facing Our History, Shaping the Future and Teaching Divided Histories: A Critical Analysis}

As FOHSTF and TDH are designed to support history teaching's wider remit and have explicitly targeted the social utility of history teaching as a central aim, arguably, they signpost possibilities for dialogue between educators and psychologists. FOHSTF is an offshoot of the Bostonbased organisation, Facing History and Ourselves. FOHSTF has evolved from the Facing History philosophy, which began with Holocaust education and the power of human agency to bring change if 'bystanders' can be transformed to 'upstanders' in opposition to social injustice. Internationally, the work of Facing History has been adapted in a number of conflict-affected contexts including South Africa and Rwanda to address the legacies of conflict, but its approach has also been criticised, particularly with regard to its role as a conduit for disciplinary understanding of history (Schweber 2004). TDH is a local NI initiative; its philosophy is rooted in the belief that the use of moving image and digital technologies to develop creative and critical skills can 'liberate and empower' young people to engage practically with issues of conflict and division (Nerve Centre 2014).

Similarities and differences in the ways social psychological concepts and terms are applied within the two project rationales and documents will be analysed through a social psychological lens as well as from the perspective of a history educator and researcher who is convinced of his subject's contribution to wider societal transformation from conflict, but also of the vital need to preserve its historical disciplinary integrity. This allows an exploration of the potential tensions arising from the ways in which the projects are related to the curriculum, and how history educators involved in such projects might incorporate social psychological terms and concepts in their teaching.

Unsurprisingly, given the importance of gaining access to schools, the literature of both projects strongly flags up their relevance to the statutory curriculum and their utility in fulfilling its objectives. For example, FOHSTF describes itself as 'fully aligned' to the revised NI History Curriculum, noting that it is particularly suitable for pupils at Key Stage 3 (KS3 is for pupils aged eleven to fourteen years) and is noted also to be compatible with citizenship classes and suitable for cross-curricular and whole school approaches consistent with the Department of Education's Community Relations Equality and Diversity (CRED) Policy 
(DENI 2011). The project is therefore clearly aligned to the curriculum, and this is reinforced by a schematic which explicitly lays out a detailed (term by term over the three years) overview of how the project might be implemented at KS3, with how each element of the statutory requirements is addressed.

In contrast to the FOHSTF project, TDH initially focuses largely on the local context of NI with references to civil rights in the USA and a concluding section on international comparisons. The website (http://nervecentre.org/education/teaching-divided-histories) details six modules each with six lessons, covering the Civil Rights movement, the Conflict, Pathways to Peace, the Easter Rising, the Somme and International Conflict and extensive support material is available for each. Again, the project is explicitly linked to the KS3 curriculum in a schematic, with history identified as a core area, but also appeals are made to teachers of English, media and citizenship (and to teachers in the border regions of the Republic of Ireland). Its wider remit for preparing young people as 'contributors to society' (CCEA 2007) is through teacher training to enable them 'to use moving image and digital technologies within the classroom to liberate and empower young people to engage practically with issues of conflict and division'. Both projects envisage history education as having a social purpose in a divided society and therefore might be expected to employ aspects of social psychology.

On examination, both FOHSTF and TDH were found to employ terminology drawn from or related to Social Identity Theory. Associated most strongly with Tajfel (2003), as previously noted this is one of the most widely used frameworks for social psychological research in NI (Garry and McNicholl 2015). First, investigating the philosophy underpinning FOHSTF a key aim is that 'Facing History helps pupils learn to combat prejudice with compassion, indifference with participation, and myth and misinformation with knowledge' (http://www.fohstf. co.uk/\#/about/4550679310). It seeks to do this by establishing its key ideas, first through studying the Holocaust, then focusing on the partition of Ireland and its consequences. Pupils embark on a journey, beginning 'by exploring questions of the individual and society -who am I? What makes my identity? Where has it come from? How much do I choose and how much is given to me?' This consideration of social identity is a fairly fundamental social psychological concept, which is then used as a basis for considering 'we and they'. Why and how do we as 
humans include and exclude? How does this play out in our lives? What is the role of prejudice and stereotyping, and what happens when this turns to active discrimination?' Again the concepts of social categorisation, stereotyping and prejudice are core concepts for social psychologists. The foundations thus laid, the emphasis appears to shift towards the historical, looking at the Holocaust and identifying how these concepts played out, and how choices were affected by identity, introducing the idea of 'bystanders and upstanders'. Judgement, legacy and memory feature next and the social psychology content seems less prominent, reappearing in the final, 'Choosing to participate' phase, where prevention of exclusion, prejudice and violence are the focus.

The Education and Training Inspectorate report (ETI 2013) on the project notes positively the application of the project's principles to the context of Irish history in the curriculum (the long-term and shortterm causes and consequences of the partition of Ireland). However, from a history educator's perspective Schweber's reservations on Facing History's efficacy, both in relation to historical disciplinary efficacy and in relation to effecting attitudinal change, merit consideration (Schweber 2004). The report's evaluation concentrates on teachers, finding that their ability to teach controversial and sensitive issues had been enhanced and that they had greater understanding of the role of history education in divided societies. None of the above terms emanating from social psychology are evident in the report, although the inspectors note that the effects on pupils included enhanced conflict resolution skills and crosscommunity friendships. The report concludes that 'very effective methodologies were used to develop the young people's understanding of both themselves and of others, and extend their capacity for engaging with others in the reconciliation process' (ETI 2013, p. 4). Other documentation available on the implementation of FOHSTF displays a similar dearth of reference to the social psychological concepts which appear from the general description to underpin the approach. This suggests that any conflict resolution skills and cross-community friendships that have been fostered by teachers are not explicitly related to the social psychological concepts, which are evident in the project rationale, but not its implementation or evaluation.

Turning to TDH, its stated aim for teachers is to provide them with 'the confidence, skills and specific resources and support that enables them to explore contentious history and identity in the classroom'. In addition to local networks, it is intended that participants should share 
resources, experiences and expertise internationally with an emphasis on the promotion of shared societies and the enabling of young people to explore common experiences of conflict and peacebuilding. Alongside the explicit links to the curriculum standard terminology drawn from social psychology is evident, with the concepts of identity, prejudice, discrimination all being referenced. However, subsequently, there is little evidence of the terms being used in ways consistent with social psychological concepts.

For example, TDH presents identity as strongly related to political groupings rather than as an individual and multifaceted construct, as in the Module 2 'Questions and answers' teaching resource where teachers are advised that in an activity where students are asked to create a table stating what a Nationalist and a Unionist is, 'Nationalist should be defined as a person (some students may mention that Nationalists are usually Roman Catholic) who favours political independence for a country/a union with the Irish Republic. Unionist should be defined as a person who favoured the maintaining of the political and cultural union with Great Britain (some students may mention that a Unionist in Northern Ireland was usually of the Protestant religion)'. Similar advice is offered in relation to comparing a Republican, who differs from a Nationalist by willingness to use 'any means necessary' to achieve a united Ireland, and a Loyalist, who differs from a Unionist by willingness to 'engage in violence' to maintain the union with Britain. Nationalist and Unionist political identities are thus clearly aligned with religion and Republican and Loyalist political identities clearly associated with violence. In the context of the lesson, which is titled 'Key players in the conflict', it might be argued that this binary representation is appropriate, but from a social psychological perspective this approach is unlikely to lead to reflective engagement with the concept of identity as a complex and nuanced issue. Indeed, the research of Barton and McCully (2012, pp. 399-400) drew attention to the dangers of a binary approach and the need for teachers to recognise the complexity of perspectives in the past.

In a balanced and reflective internal evaluation report (Gannon 2014), there is recognition that TDH has brought together a group of history teachers who are 'risk-taking ... with a passion for history and a personal commitment to peace and reconciliation' (Gannon 2014) and that young people have engaged with sensitive history and gained some insight into the 'other' community. Yet the author also acknowledges that the technological dimension tends to drive the learning with a 
danger that digital media production 'distracts from the process of critical analysis' (Gannon 2014). A textual analysis indicates that the single narrative presented of Northern Ireland's recent past in project materials is a balanced one, but it fails to problematise issues in a way that facilitates genuine historical enquiry. This is supported by the evaluation report, which concludes that the project's potential to fulfil its social objectives is heavily reliant on the intuitive skills of its leading practitioners. Greater exposure to applied social psychology may help to broaden the base of teacher expertise.

In summary, from the perspective of the social psychologist, both projects might be accused of drawing on, yet failing to exploit, the potential for improved intergroup relations, which might be achieved by history teaching incorporating an approach more explicitly informed by social psychology. For example, the multiple and complex nature of social identities appears relatively unexplored in TDH, while in FOHSTF, prejudice is to be fought with compassion, by the individual. Both approaches are, however, consistent with the Northern Ireland Curriculum, which clearly has a focus on the development of the individual pupil. FOHSTF (and to a lesser extent TDF) provides teachers with tools to realise the social utility of their discipline. However, the social roots and multidimensional nature of the phenomena implied by the terms used seem neglected. Social psychologists have long argued, for example, that individual prejudice is symptomatic of wider social issues rather than interpersonal ones and therefore, as Billig (1976) noted many years ago, requires a social analysis.

Moreover, there is little evidence that recent theoretical developments in social psychology have been incorporated into either of the two projects explored. Dovidio et al. (2010) note that in the wake of the Holocaust, social psychological attention was initially largely directed at identifying personality and individual differences related to prejudice, discrimination and related behaviours. This moved on over time to theories based on functional relations between groups as illustrated by social categorisation and social identity. This progression, from viewing prejudice and discrimination as a result of individual dysfunction, then as a result of normal intergroup processes and on to a more multidimensional understanding which takes into account dynamic aspects, opens up many avenues for research. This may eventually enable more effective approaches to prejudice reduction, to which the projects examined aspire. 
From the perspective of the history educator, both projects also raise questions around the respective demands of disciplinary authenticity and social utility made on teachers by a curriculum aspiring to prepare young people to be contributors to a society with deep divisions. For example, how far should teachers, even when committed to bettering community relations, be cognisant of principles of social psychology in their teaching of history? If, as is argued by one of the authors of this chapter, disciplinary integrity necessitates that it is not the role of history teaching to engage directly in aspects of prejudice reduction (McCully 2012) then has social psychology a part to play? The answer is yes, in that history teaching with social purpose should challenge the certainty of identity positions shaped by uncritical versions of the past, inherited from the community. To do so would benefit from insights into individual need and the social psychological processes which are so pertinent to community relations. We suggest that a number of tensions may emanate at least in part from how community relations orientated funders evaluate proposed projects in this area in relation to the NI Curriculum. We argue that history educators would benefit from a deeper understanding of the potential and limitations of the relationship between history teaching and social psychology theory in the context of a divided society. This would enable them to better understand history's potential and limitations in contributing to positive community relations and help them to make connections with other areas of the curriculum, including citizenship education, where contemporary attitudes can be clarified.

\section{CONCLUSION}

This preliminary analysis raises a number of tensions in relation to using history education as a tool to improve community relations in NI, between the curriculum, funding bodies, project designers and history teachers. First, the Revised Curriculum quite correctly focuses on pupil outcomes. In other words, its aims are pitched at individual level. A focus on the individual is not congruent with current thinking in social psychology, but harks back to post-war attempts to correct dysfunctional individual attitudes. Funding bodies in conflict-affected societies are often positively disposed towards projects which are explicitly linked to curriculum objectives directed towards peacebuilding and which incorporate relevant theoretically based terminology. Project designers often compete for funding and may take the curriculum into account when 
developing proposals and also use terminology borrowed from social psychology to produce a convincing proposal, but the social psychological elements may not be reflected in project implementation. History teachers, rather than social psychologists, are tasked with delivering the projects and must not only satisfy project evaluators and school inspectors, but also must meet curriculum objectives, teach sensitive and controversial issues, enable pupils to achieve good exam results and on top of all this, hope to improve community relations. Facing such demands teachers, whose training and professional identity are wrapped up in a subject specialism, are likely to retreat to the comfort of disciplinary rigour. Exposure to current ideas in social psychology and greater collaboration with social psychologists might encourage risk-taking to push the boundaries of history's social utility, even when guarding its disciplinary integrity.

\section{REFERENCES}

Allport, G. W. (1954). The nature of prejudice. Reading, Mass.: Addison-Wesley. Barton, K. C., \& McCully, A. W. (2005). History identity and the school history curriculum in Northern Ireland: An empirical study of secondary students' ideas and perspectives. Journal of Curriculum Studies, 37(1), 85-116.

Barton, K. C., \& McCully, A. W. (2010). "You can form your own point of view": Internally persuasive discourse in Northern Ireland students' encounters with history. Teachers' College Record, 112(1), 142-181.

Barton, K. C., \& McCully, A. W. (2012). Trying to "see things differently": Northern Ireland students' struggle to understand alternative historical perspectives. Theory and Research in Social Education, 40(4), 371-471.

Bell, J., Hansson, U., \& McCaffrey, N. (2010). The troubles aren't history yet. Belfast: Community Relations Council.

Billig, M. (1976). Social psychology and intergroup relations. London: Academic Press.

Billig, M. (1995). Banal nationalism. London: SAGE.

Brown, R. (2010). Prejudice: It's social psychology. Chichester: Wiley-Blackwell.

Bush, K. D., \& Saltarelli, D. (2000). The two faces of education in ethnic conflict. United Nations Children's Fund, Innocenti Research Centre, Florence, Italy. Retrieved July 23, 2016, from http://www.unicef-irc.org/publications/pdf/insight4.pdf.

Cole, E. A. (2007). Introduction: Reconciliation and history. In E. A. Cole (Ed.), Teaching the violent past: History education and reconciliation (pp. 1-28). Plymouth: Rowman and Littlefield Publishers Inc. 
CCEA (Council for Curriculum, Examinations and Assessment). (2007). History Curriculum Key Stage 3. Belfast: CCEA (2007). Retrieved July 23, 2016, from http://www.nicurriculum.org.uk/docs/key_stage_3/areas_of_learning/statutory_requirements/ks3_history.pdf.

Davies, L. (2004). Education and conflict: Complexity and chaos. London: Routledge.

Department of Education, Northern Ireland. (1991). Teachers for the 21st Century: A review of initial teacher training, consultative paper. Bangor Northern Ireland: DENI.

Department of Education, Northern Ireland. (2011). Community relations equality and diversity. Bangor: DENI. Retrieved July 23, 2016, from http:// www.ycni.org/downloads-publications/CRED/01-CRED-Policy.pdf.

Dovidio, J., Hewstone, M., Glick, P., \& Esses, V. (2010). Prejudice, stereotyping and discrimination: Theoretical and empirical overview. In J. Dovidio, M. Hewstone, P. Glick \& V. Esses (Eds.), The SAGE handbook of prejudice, stereotyping and discrimination (pp. 3-29). London: SAGE Publications Ltd.

Education and Training Inspectorate (ETI). (2006). History matters: Report on the extent to which the teaching of history in post-primary schools helps prepare young people to live in Northern Ireland's divided and increasingly pluralist society. Bangor: DENI.

Education and Training Inspectorate (ETI). (2013). Facing history and ourselves-The corrymeela project: Second interim evaluation. Bangor: DENI.

Facing our History Shaping the Future (FOHSTF) (2015). Retrieved June 2, 2016, from http://www.fohstf.co.uk/\#/the-approach/4550813929.

Furey, A., Donnelly, C., Hughes, J., \& Blaylock, D. (2016) Interpretations of national identity in post-conflict Northern Ireland: A comparison of different school settings. Research Papers in Education. Retrieved June 2, 2016, from doi:10.1080/02671522.2016.1158855.

Gallagher, T. (2004). Education in divided societies. Basingstoke: Palgrave Macmillan.

Gallagher, T. (2016). Shared education in Northern Ireland: School collaboration in divided societies. Oxford Review of Education, 42(3), 362-375.

Gannon, M. (2014). Teaching divided histories: Teachers' experiences of using digital media in teaching about recent northern ireland history. Internal paper, Londonderry: Teaching Divided Histories.

Garry, J., \& McNicholl, K. (2015). Understanding the 'Northern Irish' identity. Paper presented as part of the Knowledge Exchange Seminar Series (KESS), Parliament Buildings, Stormont, Belfast, 13 May 2015. Retrieved July 23, 2016, from http://www.niassembly.gov.uk/globalassets/documents/raise/ knowledge_exchange/briefing_papers/series4/northern_ireland_identity_ garry_mcnicholl_policy_document.pdf. 
Geeraert, N., \& Yzerbyt, V. Y. (2007). How fatiguing is dispositional suppression: Disentangling the effects of procedural rebound and ego-depletion. European Journal of Social Psychology, 37, 216-230.

Goldberg, T. (2013). "It's in my veins": Identity and disciplinary practice in students' discussions of a historical issue. Theory \& Research in Social Education, $41(1), 33-64$.

Heider, F. (1958). The psychology of interpersonal relations. New York: Wiley.

Hewstone, M. (2003). Intergroup contact: Panacea for prejudice? The Psychologist, 16(7), 352-355.

Johns, M., Schmader, T., \& Martens, A. (2005). Knowing is half the battle: Teaching stereotype threat as a means of improving women's math performance. Psychological Science, 16, 175-179.

Jones, R., \& Merriman, P. (2009). Hot, banal and everyday nationalism: Bilingual road signs in Wales. Political Geography, 28(3), 164-173.

Kitson, A. (2007). History education and reconciliation in Northern Ireland. In E. A. Cole (Ed.), Teaching the violent past: History education and reconciliation (pp. 123-154). Lanham, MD: Rowman and Littlefield.

Kolikant, Y. B.-D., \& Pollack, S. (2015). The dynamics of non-convergent learning with a conflicting other: Internally persuasive discourse as a framework for articulating successful collaborative learning. Cognition and Instruction, $33(4), 322-356$.

Korostelina, K. (2010). War of textbooks: History education in Russia and Ukraine. Communist and Post-Communist Studies, 43(2), 129-137.

Lee, P., \& Shemilt, D. (2011). The concept that dares not speak its name: Should empathy come out of the closet? Teaching History, 143, 39-49.

McCombe, J. (2006). School history and the introduction of local and global citizenship into the Northern Ireland curriculum: The views of history teachers. Unpublished PhD thesis, University of Ulster.

McCully, A. (2005). Controversial issues, citizenship and history. In G. Mills (Ed.), Teaching sensitive and controversial issues in history (pp. 34-43). Nottingham: History Teacher Education Network.

McCully, A. (2012). History teaching, conflict and the legacy of the past. Education, Citizenship and Social Justice, 7(2), 145-159.

Nerve Centre. (2014). Teaching divided histories. Retrieved July 23, 2016, from http://www.nervecentre.org/teachingdividedhistories.

Northern Ireland Government. (2013). Together: Building a united community. Retrieved July 23, 2016, from https://www.executiveoffice-ni.gov.uk/articles/together-building-united-community.

Northern Ireland Statistical Research Agency (NISRA). (2011). 2011 Census Retrieved July 23, 2016, from http://www.nisra.gov.uk/Census/2011Census. html.

Richardson, N., \& Gallagher, T. (2011). Education for diversity and mutual understanding: The experience of Northern Ireland. Oxford: Peter Lang. 
Schweber, S. (2004). Making sense of the Holocaust. New York: Teachers' College Press.

Shemilt, D. (1980). History 13-16 evaluation study. Edinburgh: Holmes McDonald.

Skey, M. (2009). The national in everyday life: A critical engagement with Michael Billig's thesis of banal nationalism. The Sociological Review, 57(2), 331-346.

Smith, A., \& Vaux, T. (2003). Education, conflict and international development. London: Department of International Development.

Smith, M. E. (2005). Reckoning with the past: Teaching history in Northern Ireland. Lanham: Lexington Books.

Steele, C. M. (1997). A threat in the air: How stereotypes shape intellectual identity and performance. American Psychologist, 52, 613-629.

Stevenson, C., \& Muldoon, O. (2010). Socio-political context and accounts of national identity in adolescence. British Journal of Social Psychology, 49(3), 583-599.

Stewart, T. L., Latu, I. M., Kawakami, K., \& Myers, A. C. (2010). Consider the situation: Reducing automatic stereotyping through situational attribution training. Journal of Experimental Social Psychology, 46(1), 221-225.

Tajfel, H. (2003). Emotional prejudice, essentialism and nationalism-The 2002 tajfel lecture. European Journal of Social Psychology, 33(6), 703-717.

Tajfel, H., \& Turner, J. (1979). An integrative theory of intergroup conflict. In W. G. Austin \& S. Worchel (Eds.), The social psychology of intergroup relations (pp. 94-109). Monterey, CA: Brooks-Cole.

Tajfel, H., \& Turner, J. C. (1986). The social identity theory of inter-group behavior. In S. Worchel \& L. W. Austin (Eds.), Psychology of intergroup relations. Chicago: Nelson-Hall.

Trew, K. (1998). The Northern Irish identity. In A. J. Kershen (Ed.), A question of identity (pp. 60-76). Aldershot: Ashgate.

\section{Authors' Biography}

Alan McCully is a Senior Lecturer at Ulster University. His research interests are in the fields of teaching history and citizenship education in divided societies. Particularly, his work has focused on the interface between history learned in schools and that encountered in families and communities, and on the pedagogy of teaching sensitive and controversial issues. Current work includes comparative studies in the two jurisdictions in Ireland. He has published in peer-reviewed journals such as Educational Review, Compare, Teachers' College Review and Journal of Curriculum Studies. 
Jacqueline Reilly is a Senior Lecturer in Education at Ulster University. Her research interests lie broadly within the area of education for social justice and encompass education for local and global citizenship, human rights education and training, and peace education, particularly with a focus on issues of identity and divided societies. She is currently exploring the potential of social psychology to contribute to history teaching in divided societies and the experiences of ethnic minority students in such contexts. She has published papers in peerreviewed journals such as Compare: A Journal of International and Comparative Education, Journal of Peace Psychology, Comparative Education and Journal of Social Issues.

Open Access This chapter is licensed under the terms of the Creative Commons Attribution 4.0 International License (http://creativecommons.org/licenses/ by $/ 4.0 /$ ), which permits use, sharing, adaptation, distribution and reproduction in any medium or format, as long as you give appropriate credit to the original author(s) and the source, provide a link to the Creative Commons license and indicate if changes were made.

The images or other third party material in this chapter are included in the chapter's Creative Commons license, unless indicated otherwise in a credit line to the material. If material is not included in the chapter's Creative Commons license and your intended use is not permitted by statutory regulation or exceeds the permitted use, you will need to obtain permission directly from the copyright holder.

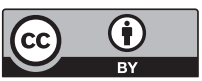

